RESEARCH ARTICLE

\title{
An Empirical-Causative Analysis of the Politics of Xenophobia in South Africa
}

\author{
Olawale Olufemi Akinrinde ${ }^{1} \llbracket$, Usman Tar $^{2}$ \\ ${ }^{1}$ Department of Political Science, Osun State University, NIGERIA \\ 2 Nigerian Defence Academy, Kaduna, NIGERIA \\ \olawale.akinrinde@uniosun.edu.ng
}

\section{อ OPEN ACCESS}

Citation: Akinrinde, O. O., \& Tar, U. (2021). An EmpiricalCausative Analysis of the Politics of Xenophobia in South Africa. Law Research Review Quarterly, 7(4), 383-402. https://doi.org/10.15294/Irrq.v $7 \mathrm{i} 4.48055$

Submitted : June 7, 2021

Revised : August 11, 2021

Accepted : November 10, 2021

(C) The Author(s)

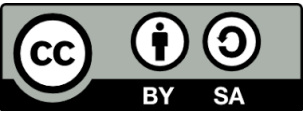

This work is licensed under a Creative Commons Attribution-ShareAlike 4.0 International License. All writings published in this journal are personal views of the authors and do not represent the views of this journal and the author's affiliated institutions.

ISSN 2716-3415

Law Research Review Quarterly published by Faculty of Law, Universitas Negeri Semarang, Indonesia. Published quarterly on February, May, August, and November.

\section{Abstract}

Several scholarly and scientific attentions have indeed been geared towards the studies on xenophobia in South Africa, but little and very limited interrogation have been devoted to its precipitating politics. Extant works and studies on xenophobia in South Africa, in addition to their differing perspectives, have focused more on how to address the xenophobic reality rather than trying to understand why the politics of xenophobia has persisted unabatedly despite several remedial interventions from government and key stakeholders. This study bridges the gap by attempting to, very importantly, understand and advance reasons as to why the politics has continued against all efforts geared towards addressing it. While Brown Harry's scapegoating thesis, Pillay's relative deprivation of South African blacks and Crush's cultural explanation amongst many others have attempted to offer empirical views on the manifestation of xenophobia in South Africa, that which is central to the understanding of the xenophobic phenomenon was innocently overlooked. The study therefore sees "politics" has been central to any attempt to understanding the manifestation of xenophobia in South Africa. The overwhelming scientific discourses and perspectives offered by this study on the politics of xenophobia would therefore help in bridging the gap in the extant literature and the body of knowledge.

Keywords: Politics, Politics of Xenophobia, Scapegoating, Economic Materialism, South Africa 


\section{INTRODUCTION}

Basically, some of the promises the post-apartheid South Africa held were, among other things, increased standard of living, high employment rate and improved literacy level. These were no doubts, the motivating factors for the general acceptance and support for the anti-apartheid movements during the many years of inglorious apartheid reigns in South Africa (Akinrinde, 2020). No doubts, South Africa's transition from the inglorious servitude of apartheid system to democracy was founded on negotiated settlements in which certain promises were made for the benefits of the indigenous South Africans but which ended up not honoured, thereby leaving some pertinent questions unanswered. This part failure to resolve national problems can, to an extent, be attributed to South Africa's national interests being on a certain level based on Africa's prosperity and stability, an indication of South Africa's liberal foreign policy (Hendricks and Whiteman, 2004: 4).

In support of this, Nyamnjoh (2006: 5) indicates that South Africa endorsed the method of economic and political liberalism, in which the preference of equality without justice was implemented. Thus, the liberal nature of South African foreign policy can be attributed as being one of the causes of the growing socioeconomic gaps between the rich white South Africans and the poor black South Africans on the one hand, and between the rich black South Africans and the poor black South Africans on the other hand. What this implies is that this social condition has therefore provided a fertile breeding ground for the politics of xenophobia in South Africa. The adoption of the principle of equality without justice thus created socioeconomic tensions especially as the average underprivileged black South Africans realised that their constitutional rights were seen to being undermined as a result of the failure of the postapartheid South African governments to deliver the material benefits of citizenship, as well as the fact that the indigenous black South African citizens now needs to continuously compete with foreigners to make ends meet (Nyamnjoh, 2006: 5). This is coupled with the fact that South Africa being one of the continent's leading economies and most industrialized country, remained embroiled in the problems of severe socioeconomic inequality and discrimination in the 
distribution of wealth in both the social and economic spheres. This continuing and widening disparity in wealth distribution has furthered a very serious and significant gap between the rich and the poor, thereby building up resentment and frustration amongst the ordinary citizens, especially the blacks South Africans (Akinrinde, 2020). The dashed expectations of the South African citizens, especially the blacks over the unsatisfactory and inadequate rate of social service delivery and consultation in general, with regards to housing conditions and provisions and administration have further compounded the xenophobic undergrowth in South Africa (HSRC, 2008: 6). These sentiments and loss of hopes amongst the people have, over time, exacerbated the xenophobic politics and various forms of violence, among which are xenophobic hostilities, resentments, attacks against black migrants, especially those whom the indigenous black South Africans perceive as social and economic threats. This explains, according to Nyamnjoh, why black immigrants are often the target of the xenophobic politics and attacks (Nyamnjoh, 2006: 38-39).

Nyamnjoh further submits that the black African migrants, many of whom are classified as aliens or called 'Makwerekwere', are seen as direct social and economic threats by highly socioeconomically disadvantaged South African blacks. 'Makwerekwere', as a slang word for foreigners, especially illegal immigrants, implies different things in different contexts. The term implies 'a black person who cannot demonstrate mastery of the local South African languages, and one who hails from a country assumed to be economically and culturally backward in relation to South Africa' (Mamokhosi et al., 2011: 134; Nyamnjoh, 2006: 39).

Furthermore, with reference to 'Makwerekwere', the reasons for such a xenophobic stereotyping of black migrants by indigenous black South Africans is because, as Mamokhosi et al (2011: 134) puts it, the black migrants compete with the indigenous black South Africans over the limited scarce resources, social services and public services such as schools, medical care, infrastructure, land, housing, informal trading opportunities, insufficient job opportunities especially considering the reality that unemployment and retrenchment rates are high whilst also offering their labour and services at cheaper rates in comparison with those of the black South Africans, many of 
whom are not only lazy, but prefer to rely on social supports from the government.

\section{RESULT AND DISCUSSION}

\section{A. The Politics of Xenophobia in South Africa: Whose Faults?}

Contributing to the xenophobic manifestations are factors such as: the nature of the physical features or the appearance of certain foreigners; the resentment of their economic successes; fear of foreigners bringing in diseases; concerns that they may marry South Africans; squatting in certain areas; not paying taxes while engaging in informal business and indulging in criminal activities (Minnar, 2005: 293; Nyamnjoh, 2006: 41; Mamokhosi et al, 2011: 135). Furthermore, according to Zondi (2008: 28), the history of South Africa's economy demonstrates how distinct eras (apartheid and post-apartheid) and political regimes have contributed to a "history of socioeconomic disparity" among South Africans. The coexistence of enormous riches and abysmal poverty, as shown by congestion and poverty in Alexandra and the affluent suburban district of Sandton, is one of the numerous long-term repercussions of apartheid on South African society. In truth, most poor settlements on the outskirts of large cities in South Africa are overcrowded incubators of poverty, social estrangement, and cutthroat struggle for scarce resources, with black South African teenagers dominating the poorest of the poor (Mamokhosi et al, 2011: 135; Zondi, 2008: 28-29). It is obvious that economic inequality plays a crucial role in violent xenophobic crimes; as a result, countries with large income disparities have a higher prevalence of crime (Nell, 2009: 235). According to Obademi and Uadiale (2004: 177), poor societies are more likely to experience civil upheaval and poverty. As a result, poverty and the problems of xenophobic violence, criminality, and other social maladies that affect the poor in South Africa today are inextricably linked. Based on this knowledge, it is self-evident that the repeating wave of xenophobic violence in South Africa is frequently triggered by discontent among the country's poor blacks. This is exacerbated when one considers how the impoverished have historically been denied access to limited productive resources. 
Unemployment, poverty, and insufficient or nonexistent service delivery are the most common socioeconomic drivers of xenophobia. Unemployment is a societal problem that occurs when a person is unable to find work. Poverty, according to Draman (2003: 2), is a global phenomenon and a culturally based concept with several definitions. In the context, poverty refers to a situation in which people are deprived of fundamental human needs such as food, safe drinking water, sanitation, health, shelter, education, and information due to a lack of income or access. Despite South Africa's high unemployment rates, the migration of foreigners continues to grow, including both legal and illegal immigrants and refugees fleeing conflict or instability in their home countries in quest of a better life. For example, several African countries, such as Zimbabwe, are currently experiencing socioeconomic and political difficulties. This has resulted in many Zimbabweans and other Africans coming to South Africa to seek refuge and greener pastures, thereby adding to the present pressure on already limited resources (Harvey, 2008: 9). The general belief of the South African blacks is that these foreigners should stay at home and try to resolve their own problems rather than emigrate and add to the already prevalent problems in South Africa.

The very fact of being unemployed predisposes a person to poverty, which explains South African blacks' displeasure with immigrants and their hostility toward them as job stealers (Mamokhosi et al, 2011: 135). People complain about degree holders walking the streets without jobs because corporations have given jobs to immigrants, according to Danso and McDonald (2000: 14). For Olumide Omodunbi, "The rising level of poverty, unemployment and illiteracy are undergrowth of post-apartheid system. They are prevalent amongst the black South Africans and not the South African whites. Majority of black South African on the streets are mostly unemployed and uneducated blacks" (Omodunbi, IDI, Lagos, 20 ${ }^{\text {th }}$ Sept, 2019).

\section{B. The Politics of Xenophobia and the Politics of Economic Relations: Mapping the Intersection}

Corroborating the elicited primary data, Harris (2002: 171-172) uses the 'scapegoat' theory in which he explains that the feelings of discontent and frustration due to 
deprivation and poverty in relation to a lack of resources and jobs, causes anger in the locals. Filled with this anger and frustration, the indigenous black South Africans who make up the majority of the population, tend to look for targets to blame. In this situation, black African migrants, who make up a minority of the population, become the ready-made and easiest scapegoats for the indigenous black South Africans' frustrations, difficulties, and animosity. This is especially true when one considers that they are viewed as threats and as contributing to the plight of indigenous black South Africans and their precarious socioeconomic state. In addition to unemployment and poverty, there is the issue of service delivery, which is linked to socioeconomic causes.

The post-apartheid realities have been a long way from the expectations of the people. This is exemplified by the 2015 Living Conditions Survey (LCS) performed by the South African Department of Statistics, which indicated that over half of South African adults (49.2\%) live below the upper-bound poverty line (UPBL) (South Africa Department of Statistics, 2020). Furthermore, race-based discrimination is an all-pervasive feature of South African culture, and it is, without a doubt, one of the societal reasons why others' non-acceptance is manifested through violent assaults. However, these difficulties of racial discrimination and non-acceptance of others are also an indicator of a problem with cultural differences, which leads to the mobilization of support for disturbance, which is regarded a major source of xenophobia. As a result, according to Nell (2009: 235-236), it is hard to comprehend the current crisis without fully accounting for the circumstances that shaped South Africa's socioeconomic and cultural-historical background. Putting these factors together, Zondi (2008: 28) says that it is the way in which indigenous black South African inhabitants on the outskirts of towns, in response to intolerable socio-economic conditions such as cries against overcrowding and bad settlements, unemployment, poverty, and neglect, blame outsiders for their plight.

This explains why of the population of South African Adults living below the poverty line, Gauteng and the Western Cape had the lowest proportions of adults living in poverty (South Africa Department of Statistics, 2020). The provinces with the highest numbers of adults living in 
poverty are, according to the Living Conditions Survey by SADS, 2015, are Limpopo (67.5\%), Eastern Cape (67.3\%), KwaZulu-Natal (60.7\%) and Northwest with (59.6\%). For these four provinces, significantly more than half of their populations were living in poverty. Gauteng and Western Cape therefore ranked highest in poverty rate with $29.3 \%$ and $33.2 \%$ respectively.

Coupled with this finding, the unemployment rate in South Africa has expectedly increased to $29 \%$ in the second quarter of 2019 from $27.6 \%$ in the previous period. As reported by Trading-Economics in South Africa, it was the highest jobless rate since 2003, as the number of unemployed roses from 455,000 to 6.65 million. With this new unemployment rate of 2019, South Africa now falls in the category of countries with the highest unemployment in Africa with Congo (46.10\%), Namibia (33.40\%), Angola (29.00\%), South Africa (29.00\%), Mozambique (25.04\%), Lesotho $(23.60 \%)$, and Nigeria $(23.10 \%)$ in first, second, third, fourth, fifth, sixth, and seventh positions respectively (Trading-Economics, 2019). Intriguingly, the hotbeds and launch sites of xenophobic attacks in South Africa had the highest rates of poverty and unemployment. Xenophobic attacks have been more common in towns and suburbs in provinces such as Gauteng, KwaZulu-Natal, Northwest, West Cape, and Eastern Cape than in other areas with superior Living Conditions Assessments and Employment rates.

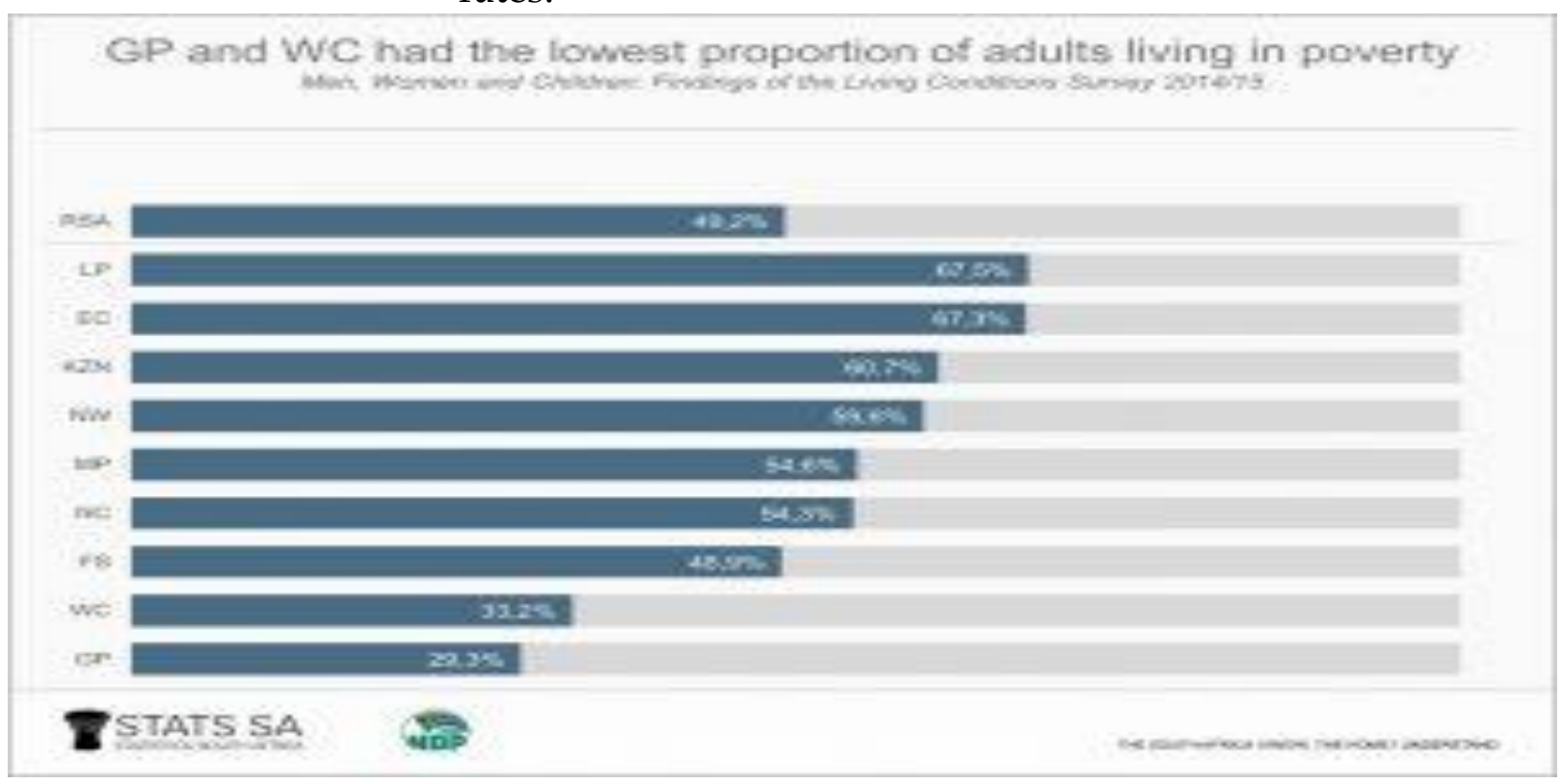

Figure 1. South Africans' Living Conditions Survey

Source: South Africa Department of Statistics (Living Conditions Survey), 2015 
Available evidence has shown that most xenophobic attacks had taken place more in areas and towns with alarming rates of poverty and unemployment (Crush, 2008b). The above finding is further supported on Table 1.

Table 1. A Compilation of Xenophobic Attacks in Post-Apartheid South Africa

\begin{tabular}{|c|c|c|c|c|}
\hline $\mathrm{S} / \mathrm{N}$ & TOWN & $\begin{array}{c}\text { NATURE OF XENOPHOBIC } \\
\text { ATTACK }\end{array}$ & CASUALTIES & YEAR \\
\hline 1. & Alexandra Township & $\begin{array}{l}\text { Operation Buyelekhaya (Go back } \\
\text { home) (Landau et al., 2005: 30) }\end{array}$ & None & 1995 \\
\hline 2. & $\begin{array}{l}\text { Pretoria (Occurred in } \\
\text { the Train) }\end{array}$ & $\begin{array}{l}\text { Physical Assault of three foreign } \\
\text { nationals in a train by South Africans } \\
\text { after returning from a rally on the } \\
\text { rising level of unemployment (Crush, } \\
\text { 2001). }\end{array}$ & $\begin{array}{l}\text { None but varying } \\
\text { degrees of injuries } \\
\text { sustained. }\end{array}$ & 1998 \\
\hline 3. & Pretoria & $\begin{array}{l}\text { A Rwanda refugee was beaten up by } \\
\text { a South African taxi driver because he } \\
\text { is foreign (Crush, 2001). }\end{array}$ & $\begin{array}{l}\text { None but heavy } \\
\text { injury sustained by } \\
\text { victim }\end{array}$ & 1998 \\
\hline 4. & A Nation-wide attack & $\begin{array}{l}\text { A nation-wide xenophobic attack on } \\
\text { black foreign nationals left } 30 \\
\text { refugees killed (SABC, 2015). }\end{array}$ & 30 & 1999 \\
\hline 5. & Zandspruit-Natal & $\begin{array}{l}\text { In August, South Africans burnt } \\
\text { down shacks of Zimbabwean } \\
\text { foreigners living in the settlement } \\
(\text { SABC, 2008). }\end{array}$ & $\begin{array}{l}\text { None except loss of } \\
\text { properties and } \\
\text { homes, making the } \\
\text { Zimbabwean national } \\
\text { homeless and } \\
\text { dejected. }\end{array}$ & 2000 \\
\hline 6. & $\begin{array}{l}\text { Pretoria (Occurred in } \\
\text { the train). }\end{array}$ & $\begin{array}{l}\text { A Sudanese refugee named James } \\
\text { Diop was seriously injured after being } \\
\text { thrown from a train in Pretoria by a } \\
\text { group of armed South Africans } \\
\text { (Harris, 2008). }\end{array}$ & $\begin{array}{l}\text { None but victim was } \\
\text { badly injured. }\end{array}$ & 2001 \\
\hline 7. & Cape Town City & $\begin{array}{l}22 \text { black foreign nationals were } \\
\text { brutally stabbed in a xenophobic } \\
\text { manner by groups of South African } \\
\text { xenophobes (Harris, 2002). }\end{array}$ & $\begin{array}{l}\text { None except the fatal } \\
\text { injuries that were } \\
\text { sustained by victims. }\end{array}$ & 2001 \\
\hline 8. & $\begin{array}{l}\text { Botha Ville, Free- } \\
\text { State }\end{array}$ & $\begin{array}{l}\text { Zimbabwean and Somali refugees } \\
\text { were fatally assaulted and beaten in } \\
\text { Botha Ville, Free-State in } 2005 \\
\text { (CORMASA, 2007). }\end{array}$ & None & 2005 \\
\hline 9. & $\begin{array}{l}\text { A Township outside } \\
\text { Knysna }\end{array}$ & $\begin{array}{l}\text { A number of Somali shop-owners and } \\
\text { traders were chased out of a township } \\
\text { near Knysna. Following this } \\
\text { xenophobic clampdown, more than } \\
30 \text { shops were damaged (CORMSA, } \\
2007 \text { ). }\end{array}$ & $\begin{array}{l}\text { No loss of lives but } \\
\text { properties was } \\
\text { rampantly destroyed. }\end{array}$ & 2007 \\
\hline 10. & Cape Town & $\begin{array}{l}\text { In August 2007, } 13 \text { Somali } \\
\text { shopkeepers were found gruesomely } \\
\text { murdered in their shops in Cape }\end{array}$ & 13 & 2007 \\
\hline
\end{tabular}


Town. Nothing was however stolen from these shops (CORMSA, 2007).

11. Entire Country

12. East Rand

13. Botshabelo, Free State

14. South Africa

15. Durban

16. City of Tshwane

17. Pretoria
A xenophobic onslaught across the entire that left many houses burnt, 342 shops looted and 213 burnt down with Hundreds of people injured while thousands were chased away (BBC, 2019).

A Mozambican national, Ernesto Alfabeto Nhamuave, a-35 year old trader, was beaten, stabbed and set ablaze in Ramaphosa informal settlement on the East Rand.

Also, From 14 to 17 November 2009, 3000 Zimbabwean citizens living in the rural community of De Doorns, an informal settlement near Breede Valley Municipality, in the Western Cape was displaced as a result of xenophobic attacks (BBC, 2019).

New attacks in parts of Cape Town and in Botshabelo in the Free State (BBC, 2019)

125 Nigerians were reported to have been xenophobically deported from SA by South African Authorities upon an allegation of possession of fake yellow fever vacination certificate.

Violent xenophobic attacks against African nationals by black South Africans following the Zulu King Goodwill Zwelithini's remarks that foreign African nationals were responsible for crimes in South Africa (BBC, 2019)

A series of protests erupted in Tshwane from June 20 to June 23, 2016. Despite the fact that the riots were caused by political unrest within the ANC. Shops and micro businesses owned by Somali, Pakistani, and other foreigners were looted, and a number of foreigners were assaulted (BBC, 2019).

A large-scale, officially recognized anti-immigrant protest was organized and held in Pretoria on Friday, February 24, 2017. Protesters marched to the Foreign Ministry, where they presented the government with a
More than 60 lives 2008 were lost.

Internal

2009

Displacement of persons, most especially, black foreigners, and several injuries were sustained.

No casualty recorded

2012

No casualty recorded

March, 2012

5 foreign African

nationals were

reportedly killed

Desruction and looting of properties with several injuries sustained.

No casualty recorded 
18. Soweto Township

19. Durban

20. Johannesbourg petition. Protesters accused immigrants of stealing jobs from South Africans and causing crime, saying that "they are arrogant and don't know how to talk to people, particularly Nigerians." During the march, 136 demonstrators were arrested (BBC, 2019)

Violent xenophobic onslaught initiated by the black South African community against foreign African nationals in the aftermath of a reported killing of a South African man whom had robbed a shop belonging to a Somalian (BBC, 2019)

Xenophobic protests targeting African 3 were killed. immigrants erupted in Durban on March 25, 2019. Around a hundred people targeted foreign-owned businesses, forcing around 50 people to take refuge in a nearby police station and mosque. The riot claimed the lives of three people. President Cyril Ramaphosa's speech at the ANC's election manifesto for the 2019 South African general election, in which Ramaphosa pledged to crack down on undocumented immigrants involved in illegal activities, has been blamed for inflaming xenophobia. Both the South African government and political parties condemned the attacks on foreigners (BBC, 2019). Following the death of a taxi driver on September 1, 2019, riots and looting targeting shops run by foreign nationals erupted in Jeppestown and Johannesburg. By the third day of September, 189 people had been arrested for looting. During the incident, about 50 businesses, mostly owned by Nigerians from other parts of the continent, were reportedly destroyed or damaged. The disturbances took place in the midst of a nationwide truck driver strike, which was protesting the hiring of non-South African truckers. Amid attacks on foreigners, 640 Nigerians signed up for free flights to Nigeria in September 2019. Refugees staged a
3 were reportedly August, killed 2018

12 were killed. 
sit-in demonstration in Greenmarket

Square in Cape Town in response to the riots (BBC, 2019).

Source: Compiled by Researcher, 2019

In the above table, it is clear that aside Pretoria and Cape, 90 percent of the areas where xenophobic attacks had taken place currently have the highest rates of poverty and unemployment in South Africa. The unavailability of jobs coupled with the pervasive level of poverty in most of the South African townships, there is however an intense contestation between indigenous South Africans and black foreign nationals (who naturally populate the informal and township areas) over the scarcely available resources.

Similarly, the tables below further showed how the xenophobic attacks have continued to increase in the postapartheid period and occurred more in areas and provinces that are black dominated.

\section{South Africa attacks}

\begin{tabular}{|l|r|}
\hline Xenophobic violence incidents by Province, 1994-2018 & 212 \\
\hline Gauteng & 111 \\
\hline KwaZulu-Natal & 67 \\
\hline Limpopo & 40 \\
\hline Eastern Cape & 33 \\
\hline Mpumalanga & 22 \\
\hline North West & 20 \\
\hline Free State & 19 \\
\hline Northern Cape & 5 \\
\hline Source: Xenowatch, African Centre for Migration \& Society & B B C \\
\hline
\end{tabular}

Figure 2. Xenophobic attacks by provinces, 1994-2018

The government has been primarily responsible for the repeating xenophobic scenario in South Africa, particularly in terms of poor socioeconomic service delivery. Although it is true that the state's machinery will never be able to meet the requirements of all citizens, the government has contributed to xenophobic attacks on foreign nationals, even if it is not directly to blame (Mamokhosi et al, 2011: 135). This is because, as the Human Science Research Council (HSRC) (2008: 6) points out, the South African people's xenophobic 
hostility and resentment of black foreign migrants is exacerbated by citizens' frustrations with the government's slow pace of social service delivery and provisions in the areas of housing, administration, and employment. The government's incapacity to meet the people's socioeconomic requirements has been highlighted by the country's poor service delivery system, which has resulted in uncharitable socioeconomic situations. Webb explains how most consecutive South African governments and their various ministries have tended to spend little of the fiscal year's budgets allotted to them for the objectives of serving the people and bringing development to the various communities (Webb, 2008: 6). Take, for example, the Joint Budget Committee of the South African Parliament, which concluded that eight government ministries, including "Home Affairs, Health, and Transport," had failed to produce the information required by the Committee on time in the aftermath of the 2008 xenophobic attacks (Webb, 2008: 6). In terms of budget allocation, the government's national departments have been accused of not spending their capital expenditure (Mamokhosi et al, 2011: 135).

According to a Report, by the third quarter of the 2007/2008 financial year, eighteen departments had spent less than fifty per cent and four less than twenty per cent of their allocated resources (Webb, 2008: 6). With such incapability to effectively manage the finance allocation by government departments, the Government was also blamed for failing to take serious consideration of matters pertaining to job creation and economic development (Webb, 2008: 6). The failure of the South African government to promote human development, as well as insufficient social services, unemployment, decaying infrastructure, and persistent poverty, provide validity and empirical validity to the role of socioeconomic banes in South Africa's xenophobic politics and attacks.

As a result, the study's materialist theoretical base, together with the Political-Economy method, no doubt explains the predominance of material and economic resources and/or sub-structure in determining the form of the sort of politics that results.

The resulting conflagration between indigenous South Africans who had been materially, socially, economically and politically deprived by many years' apartheid system 
and black foreign nationals over jobs, trading businesses, and the scarce resources captures the inherent politics of the frequent manifestation of xenophobia in South Africa. This materialist explanation has also been corroborated by Brown Harris in Scapegoating thesis. The scapegoat thesis empirically locates xenophobia within the context of the ensuing South Africa's transition from an authoritarian rule to a democracy (Harris, 2002: 170). The exhilaration of liberty and the prospect of a higher quality of life, as well as the payment of self-government/democracy dividends, faded quickly. Despite the end of apartheid, economic apartheid, millions of black South Africans continue to suffer from great social evils, according to Ukwandu (2017) and Statistics South Africa (2020), as the social, economic, and political injustices of decades of segregation, colonialism, and apartheid had catastrophic development impacts. The inability of the ANC-led post-apartheid South African government to meet the aspirations of its people cut short South Africans' heightened aspirations in the postapartheid state. Limited resources, widening disparities between rich and poor, unequal income distribution, and rising poverty have all contributed to people's disenchantment and frustration with the post-apartheid South African state. Mrs. Oluwatoyin Odiete, a respected Nigerian diplomatic attaché who had recently returned from the Nigerian High Commission in Pretoria as a Diplomatic Attache, fully supported this view. In her words:

Xenophobia can be viewed as a manifestation of the struggle for scarce resources in a particular area. In view of these, I would strongly agree that the menace called Xenophobia lies in the fierce struggle between the materially dominant black foreigners, predominantly, the indigenous and materially disadvantaged South Africans. This is due to the fact that the materially disadvantaged South Africans are generally lazy and depend majorly on the government to provide everything for them, take their men for instance, they are generally lazy and takes to drinking and womanizing rather than working hard to make ends meet for their immediate family, while their women are hardworking and generally serious-minded. The problem of Xenophobia in South Africa is majorly as a result of their damaged ego which is fuelled by poverty, Unemployment and illiteracy amongst other things, which can be traced to 
apartheid era when the economy of South Africa was predominantly in the hands of the white. Similarly, with the hope that with a black man at the helms of power, an average South African man hopes to get everything on a platter of gold. It is important to state that an average South African man is lazy and depends on the government to provide the basic necessities of life. However, with the melt down of the economy and coupled with recession and corruption problems which started way back during the era of Jacob Zuma down to President Ramaphosa, the country has had to deal with adjustment of their budgetary allocations in sector like Health, Agriculture, Culture and Tourism. In this year (2019 emphasis here is researcher's), education had the highest budgetary allocation, and this is drawn from the fact that an average South African man does not value education and are pushed and paid monthly allowances to go to school. However, in recent times these allowances are not being paid regularly and the foreign student get to get the top positions and are awarded jobs in big firms and get this allocation that meant to be for its citizens, and as a result they do not get job (Odiete, KII, Abuja, 2nd Dec, 2019).

Odiete's account corroborates the empirical proposition of this study that the recurring manifestation of the xenophobic politics is the constant struggle for the scarcely available resources between indigenous black South Africans who had been disadvantaged by apartheid system and ANC-leadership deficits, and the teeming black nationals in SA. Many of the indigenous black South Africans that are unemployed thus see many of the foreign black nationals as threat to their access to the limited social and economic resources. Thus, this partly explains why many of the European nationals and many other foreign nationals mostly from the developed climes are usually excluded from the ring of the xenophobic politics and attacks.

To summarize, the realities arising from the periodic manifestations of xenophobia in South Africa show that politics plays a significant role in the emergence of the xenophobic problem. The politics that underpin the appearance of xenophobia in South Africa has long been disregarded in previous and recent research on xenophobia in South Africa and Africa as a whole. Whereas the inherent 
politics has become a result of an intense struggle and competition over scarce resources between indigenous black South Africans and black foreign African nationals in most black-dominated areas in South Africa, politics is further compounded by prevailing poor socioeconomic conditions and inequalities between indigenous black South Africans and white South Africans in most black-dominated areas in South Africa. Poverty, unemployment, and insufficient social services resulting from poor governance and the longterm apartheid system have continued to breed a number of poor indigenous black communities in South Africa. The implication is intense politics, cum, struggle over almost non-existent and inadequate economic and social resources and provisions across all of South Africa's communities, particularly those dominated by blacks. This conclusion is supported by the fact that, first, only indigenous black South Africans have been primarily involved in xenophobic politics and violent attacks in South Africa. The wealthy white South African class rarely fuels or participates in xenophobic politics or violent resentments in South Africa. Second, in the post-apartheid era, most white South Africandominated cities, such as the Western and Eastern Cape, have had little or no xenophobic attacks, whereas the majority of the attacks have targeted South Africa's black communities. Importantly, no evidence has been found that Chinese, European, or American foreign nationals in South Africa were targeted in previous xenophobic attacks in the country. This finding supports the study's argument that the politics and struggle for few resources between the primarily poor black South African population and rising black African nationals are the root causes of reoccurring xenophobia in South Africa. The dominance of current terrible economic conditions and elements such as poverty, unemployment, economic instability, and others accentuate and feed this politics. Finally, xenophobic politics has continued as a result of the government's failure to address the underlying causes of the xenophobic politics. Surprisingly, the government has focused solely on using security apparatuses to combat the phenomenon, thereby ignoring how poverty, unemployment, economic and social inequities have created a fertile environment for the xenophobic politics. 


\section{CONCLUSION}

This study has demonstrated that the politics of xenophobia in South Africa has been spiral, multi-factorial and reflective of the internal socioeconomic contradictions prevalent in South Africa as with most African countries. The prevailing excruciating socioeconomic conditions such as poverty, unemployment, growing economic inequalities in the postapartheid South Africa have constantly pitted the indigenous black South Africans against black African migrants in realpolitik and a fierce power struggle over the limited and scarcely available social and economic resources and provisions in South Africa. Evidence from the field point to the culpability of factors such as high-profile corruption amongst the ruling ANC-controlled South African government; ever-rising levels of unemployment, poverty, economic inequalities and gaps between white South Africans and black South Africans; leadership deficit, and high crime rate in the continued manifestation of xenophobic attacks in South Africa. It is therefore the position of this study that until the government and relevant stakeholders frontally address the socioeconomic conditions that provide fertile grounds for unhealthy economic competition, rivalry and frustrations among the poor black communities and foreign blacks, the politics of xenophobia is unlikely to abate.

\section{DECLARATION OF CONFLICTING INTERESTS}

The Author declares that there is no potential conflict of interest in the research, authorship, and/or publication of this article.

\section{FUNDING}

None

\section{ACKNOWLEDGEMENT}

None

\section{REFERENCES}

Akinrinde, O. (2020). "Africanity and the Politics of African Xenophobia: A Study of Two Parallels." Annals of Spiru Haret University Economic Series, 20 (4), 133-151, doi: https://doi.org/10.26458/2047. 
BBC News (2019). South Africa: How common are xenophobic attacks? Available at: https://www.bbc.com/news/world-africa-47800718.

Consortium of Refugees and Migrants in South Africa (CORMSA). (2007). Protecting refugees and Asylum seekers in South Africa. Available at: http://www.cormsa.org.za/wpcontent/uploads/2008/06/cormsa07report.pdf

Crush, J. (2001). The dark side of democracy: Migration, Xenophobia and Human Rights in South Africa. International Migration, 38(6), 103-133.

Crush, J. (2008b). The perfect storm: The realities of xenophobia in contemporary South Africa. Cape Town/Kingston: Southern African Migration Project.

Crush, J. and Pendleton, W. (2004). Rationalizing Xenophobia? Citizens Attitudes to Immigration and Refugee Policy in Southern Africa. Southern African Migration Project.

Danso, R. and McDonald, D.A. (2000). Writing Xenophobia: Immigration and the Press in Post Apartheid South Africa Migration Policy Series No. 17, Cape Town: IDASA.

Draman, R. (2003). Poverty and Conflict in Africa: Explaining a Complex Relationship'. A Paper prepared for Experts Group Meeting on Africa-Canada Parliamentary Strengthening Program, Addis Ababa. May 19-23, 2003.

Harris, B. (2002). Xenophobia: A New Pathology for a new South Africa?' in Hook, D. \& Eagle, G. (eds). Psychopathology and Social Prejudice, Cape Town: UCT Press.

Harvey, E. (2008). 'Worse to Come if Conditions Don't Improve: Scramble for Jobs, Housing Ignites Violence. SA Media, 22 May, Cape Times, p 9.

Hendricks, C. and Whiteman, K. (Rapporteurs) (2004). 'South Africa in Africa: The Post-Apartheid Decade, Seminar held in Stellenbosch 29 July-1 August 2004, Seminar Report, November 2004, Cape Town: Centre for Conflict Resolution.

HSRC (Human Sciences Research Council) (2008). Citizenship, Violence and Xenophobia in South Africa: Perceptions from South African Communities,' Democracy and Governance Programme, June 2008, Human Sciences Research Council. 
Human Sciences Research Council (2008). Violence and Xenophobia in South Africa: Developing consensus, moving to action. Available at: File:///C:/Users/HP\%20PC/Downloads/5504_Hadlan d_ViolenceandxenophobiainSA\%20(3).pdf.

Landau, L.B., Ramjathan-Keogh, K. \&Singh, G. (2005). Xenophobia in South Africa and problems related to it. Forced Migration Working Paper Series \#13. Johannesburg: University of the Witwatersrand.

Minnar, A. (2005) Victimization and Rights of Foreign Migrants in South Africa,' Davis, L. and Snyman, R. (eds). Victimology in South Africa, Pretoria: Van Schaik Publishers.

Nell, I. (2009). The Tears of Xenophobia: Preaching and Violence from a South African Perspective. Practical Theology in South Africa, 24(2), 229-247.

Nyamnjoh, F.B. (2006). Insiders and Outsiders: Citizenship and Xenophobia in Contemporary Southern Africa, Dakar: CODESRIA Books.

Obademi, O.E. \& Uadiale, O. M. (2004). 'Xenophobic Killings in South Africa and Economic Globalization: Emerging Issues,' \& Nyamnjoh, F.B. (eds.) Xenophobia: A Contemporary Issue in Psychology, London, Zed Books. Pillay, D. (2008). Relative deprivation, social instability and cultures of entitlement. In S. Hassim, T. Kupe and E. Worby (Eds.). Go home or die here: Violence, xenophobia and the reinvention of difference in South Africa (93-104). Johannesburg: Wits Press.

Policy, 110 (spring): 82-96.

South African Broadcasting Corporation (2015). Xenophobic Attacks Impact Negatively on Business. April 20, 2015.

Statistics South Africa. (2020). SA Economy Sheds 2.2 million jobs in Q2 but unemployment levels drop. Retrieved March 10, 2021, http://www.statssa.gov.za/?p=13633.

Trading-Economics (2019). South Africa Unemployment Rate. Retrieved from https//: www.tradingeconomics.com at 23/10/19.

Ukwandu, D. C. (2017). Reflections on xenophobic violence in South Africa: What happens to a dream deferred? African Journal of Public Affairs, 9(9), 43-61. 
Webb, B. (2008). 'Departments Slated for Spending,' SA Media, 12 June, Star, p 6.

Zondi, S. (2008). Xenophobia Attacks: Towards Understanding of Violence against African Immigrants in South Africa. African Insight, 38(2), Africa Institute of South Africa.

\begin{abstract}
ABOUT AUTHORS
Olawale Olufemi Akinrinde is Lecturer II in the Department of Political Science at Osun State University, Nigeria, where he lectures and undertakes research in International Relations, Defence, Security and Strategic Studies. Olawale holds an outstanding Master's Degree in International Relations from the University of Ibadan, Ibadan Nigeria, and a First Class Bachelor's Degree in Political Science and International Relations from Osun State University, Nigeria. Presently at the final stages of his Doctorate Degree in Defence and Strategic Studies, Nigeria Defence Academy Kaduna, Nigeria, Olawale's works have appeared in Annals of Spiru Haret University Economic Series, Young African Leaders Journal of Development, Annals of the Costantin Brâncuși University of Târgu Jiu Letters and Social Science Series, Carnelian Journal of Law and Politics, and The Journal of International Relations, Peace Studies and Development.
\end{abstract}

Professor Usman Tar is the Endowed Chair of Defence and Security Studies at the Nigerian Defence Academy, Kaduna, Nigeria. Professor Tar, aside being an Endowed Chair, is also the Director of the Center for Military Research and Documentation at Nigerian Defence Academy, Kaduna, Nigeria. With over a hundred of peer-reviewed and empirical publications, some of Professor Tar's works include: i. Palgrave Handbook of Small Arms and Conflicts in Africa. Edited by Usman A Tar and Charles P Onwurah, London: Palgrave Macmillan, 2021 (ISBN: 978-3-030-621827) https://www.palgrave.com/gp/book/9783030621827. ii. Routledge Handbook of Counterterrorism and Counterinsurgency in Africa. Edited by Usman A Tar, London, New York: Routledge Publishers, 2021 (ISBN 9781138575394), https://www.routledge.com/RoutledgeHandbook-of-Counterterrorism-and-Counterinsurgencyin-Africa/Tar/p/book/9781138575394. iii. New Architecture 
for Regional Security in Africa: Perspectives on Counterterrorism and Counterinsurgency in the Lake Basin. Edited by Usman A Tar and Bashir Bala. Lanham MD: Lexington Books, 2020 (ISBN: 978-0-7391-9638-0) https://rowman.com/ISBN/9781498574105/NewArchitecture-of-Regional-Security-in-Africa-Perspectiveson-Counter-Terrorism-and-Counter-Insurgency-in-theLake-Chad-Basin. iv. Globalisation in Africa: Perspectives on Development, Security and the Environment, Edited by Usman A Tar, Etham B Mijah and Moses EU Tedheke, Lanham, MD, USA, Lexington Books, 2016 (ISBN: 9780739196380), https://rowman.com/ISBN/9780739196380/Globalization-inAfrica-Perspectives-on-Development-Security-and-theEnvironment. v. The Politics of Neoliberal Democracy in Africa. Authored by Usman A Tar, London: Bloomsbury (IB Tauris), $2008 \quad$ (ISBN: 9780857715760)., https://www.bloomsbury.com/uk/the-politics-ofneoliberal-democracy-in-africa-9780857715760/ 